学会賞受賞論文

\title{
精巣内インターロイキン -35 の役割 Interleukin-35 plays a pivotal role in maintaining the testicular immune privilege
}

寺山隼人 a)* 善本隆之 b)、内藤宗和 c)、平井宗一 d)、曲寧 d)、畑山直之 d)、 林省吾 d)、金沢輝久 a)、隅山香織 a)、坂部貢 a)、伊藤正裕 d)

Hayato Terayama, Takayuki Yoshimoto, Munekazu Naito, Shuichi Hirai, Ning Qu, Naoyuki Hatayama, Shogo Hayashi, Teruhisa Kanazawa, Kaori Suyama, Kou Sakabe and Masahiro Itoh

a) 東海大学医学部基礎医学系生体構造機能学

Department of Anatomy, Basic Medical Science, Tokai University School of Medicine

干 259-1193 神奈川県伊勢原市下糟屋 143

b) 東京医科大学医学総合研究所免疫制御研究部門

Department of Immunoregulation, Institute of Medical Science, Tokyo Medical University

₹ 160-8402 東京都新宿区新宿 6-1-1

c) 愛知医科大学医学部解剖学講座

Department of Anatomy, Aichi Medical University

干 480-1195 愛知県長久手市岩作雁又 1 番地 1

d) 東京医科大学人体構造学分野

Department of Anatomy, Tokyo Medical University

₹ 160-8402 東京都新宿区新宿 6-1-1

キーワード:

Interleukin-35、精巣

*Corresponding author:

寺山隼人

Tel: 0463-931121 (ext.2513)

E-mail: terahaya@tokai-u.jp

\section{要 約}

Haploid germ cells (=精子細胞・精子) は、様々な自己抗原を含んでおり、セルトリ細胞間の結合で 構成される血液一精巣関門（blood-testis barrier）によって免疫系から護られている。また、セルトリ 細胞、ライディッヒ細胞および精巣マクロファージの一部が免疫を抑制する働きを担っていることが知ら れている。さらに、精巣内で分泌されるいくつかのサイトカインが免度抑制作用を有することが明らかに なってきた。最近、新たに同定されたサイトカインである Interleukin (IL) - 35 が、免疫抑制効果を有し、 Epstein-Barr virus-Induced gene-3（EBI3）とIL-12p35（p35）のヘテロダイマーとして存在するこ とが報告された。しかしながら、精巣において IL-35がどのような役割を担っているのか未だ明らかになっ ていない。本研究では、正常マウス（12 週齢雄 C57BL/6 マウス）を用いて精巣内の EBI3 および p35 の発現を調べると共に、EBI3 および p35 を欠損させたノックアウトマウス（KO）の精巣を解析した。 
その結果、正常マウスの精巣内の EBI3 は、CD163 陽性細胞の一部（精巣内在住マクロファージ）およ び精子細胞・精子の頭部に発現していた。p35 は、EBI3 陽性およびF4/80 陽性細胞の一部、精細管の 基底膜、血管内皮細胞および精子細胞・精子の頭部に発現していた。EBI3 および p35 を欠損させた KO マウスの精巣では、有意な精子形成障害が見られた。また、精巣間質中には CD4、CD8、B220 陽性細胞 が浸潤するとともに、精巣内で IFN- $\gamma$ や IL-10 の上昇がみられた。さらに、血清中に精子細胞・精子に 対する自己抗体が認められた。本研究の結果は IL-35 を構成している EBI3 および p35 は CD 163 陽性細 胞の一部に発現し、精巣において免疫抑制の維持に関わっている可能性を示唆している。

\section{緒 言}

精細管内の生殖細胞系は精祖細胞・精母細胞・ 精子細胞・精子の一連の細胞群からなるが、免疫 寬容の時期を遥かに過ぎた思春期以降から出現 する haploid germ cells（=精子細胞・精子）は 様々な自己抗原を含むことがわかっている。しか し、精子細胞・精子は精細管のセルトリ細胞で構 成される血液一精巣関門（blood-testis barrier = BTB）内に存在するため生理的にも免疫学的 にも護られていると考えられている[1.2]。さらに、 BTB 外においても、異種組織片を精巣間質へ移 植すると、移植された組織片は他の臓器の間質に 移植した場合と比較して、拒絶されにくいとい うことが報告されている[3,4]。つまり、精巣間質 の段階で、マクロファージやライディッヒ細胞 など各細胞同士の cell-cell interaction が、Fas ligand, interleukin (IL)-10、 transforming growth factor (TGF) - $\beta$ などのサイトカインを 分泌し、精細管の内外で免疫学的抑制環境を形成 していると考えられるようになってきた[5]。

BTB の損傷や破壊が起こると、自己抗原を含 む haploid germ cells はBTB を越えて漏出し、 その結果自己抗原の曝露によって自己免疫性炎症 を引き起こす。精巣の感染症や生検による損傷は 反対側の精巣に炎症を引き起こすと報告されて いる[6]。実験的自己免疫精巣炎 (Experimental Autoimmune Orchitis：EAO）は生きた精巣細 胞（Testicular germ cell：TGC）を 2 週打きに 2 回注射することのみで誘導され、特発性男性 不妊を研究するための有用なモデルである[7]。 EAO の病理は、アポトーシス増加および精上皮 の脱落によって精子形成障害が引き起こされ、 $\mathrm{CD} 4+\mathrm{T}$ 細胞、CD8+ $\mathrm{T}$ 細胞、B 細胞およびプラ ズマ細胞の浸潤が特徴である ${ }^{[8]}$ 。最近、CD4+お よび CD8+T 細胞が産生する IFN- $y$ や IL-17、マ クロファージおよび樹状細胞が産生する IL-12
や IL-23 などのサイトカインがEAO の病因に 関係していると報告された[9,10]。IL-6/IL-12 系 サイトカインである IL-12、IL-23、IL-27 およ びIL-35 は、様々な免疫反応の調節に重要な役 割を果たす[11-13]。IL-6/IL-12 系サイトカイン は 2 つの異なるサブユニットを含むへテロダイ マーであり、IL-12、IL-23、IL-27 および IL-35 は、p40 およびp35、p40 および p19、EBI3 お よび p28、EBI3 および p35 からそれぞれなる [11-17]。IL-12 および IL-23 はヘルパーT (Th) 1 細胞および Th 17 細胞の誘導に重要な役割をそれ ぞれに果たしている[11,12]。IL-27 は抗炎症性作 用があり、初期 Th1 細胞および IL 10 を産生す る Treg 細胞（タイプ1）の分化誘導を促進し、 Th2 細胞および Th17 細胞の分化誘導を抑制す る[12,13]。IL-35 は Foxp3+T (Treg) 細胞によっ て産生される新しい抗炎症性のサイトカインであ り、Th17 細胞の分化誘導を抑制する ${ }^{[14,15]}$ 。最 近、Niedbala らは、IL35 がコラーゲン誘導性リ ウマチを抑制することを明らかにした[16]。さら に、Collison LW らは、EBI3 ノックアウトマウ ス（KO）および p35KO マウスの Treg 細胞の免 疫調整性が低下し、炎症性大腸炎の改善度が低下 したと報告している ${ }^{[15]}$ 。しかしながら、今まで 精巣における IL-35 の役割を示した報告がない。 そこで、本研究では、精巣における IL-35 の発現 および IL-35 を欠損させた時の免疫環境に与える 影響を検討することを目的とした。

\section{材料および方法}

動物は EBI3 KO マウス、p35KO マウスおよび コントロールとして KO マウスのバックグラウン ドである C57BL/6 マウス (WT) の雄（n=10 × 3）を使用した。ネンブタールの深麻酔下で心 臓から採血し、安楽殺処分後、精巣を摘出した。 


\section{1. 組織化学的観察}

12 週齢 EBI3KO、p35KO およびWT マウスか ら摘出した精巣をブアン液にて 3 日間固定した。 その後、常法通りにエタノールで脱水し、プラ スチック包埋（Technovit 7100、Kulzer 社）を 行った。 $5 \mu \mathrm{m}$ の切片をミクロトーム（HN340E; Microme 社）にて作製し、ヘマトキシリンと $2 \%$ エオシンにて染色 (HE染色) を行い光学顕微鏡 で観察し、精子形成障害のある精細管数を百分率 で算出した。

\section{2. 免疫組織学的観察}

a ）EBI3、p35、CD163 および F4/80

12 週齢 WT マウスから摘出した精巣を Optimal Cutting Temperature (OCT) コンパウンド で包埋後、迅速液体窒素で凍結、厚さ $5 \mu \mathrm{m}$ の 切片をクリオスタット（CM1900、Leica 社） にて作製した後、 $-20{ }^{\circ} \mathrm{C}$ のヤトンで 2 分間 固定し風乾した。組織切片は、非特異的染色 を阻止するため、ブロックエース（DS ファー マバイオメディカル社）10 分、メタノールに $\mathrm{H}_{2} \mathrm{O}_{2}$ (final: $0.3 \%$ ) を加えた溶液に 30 分、 VECTASTAIN ABC Elite kit (Vector 社) のブ ロッキング血清に20 分間浸漬した。次いで、 リン酸緩衝生理食塩水（PBS）で希䣋したラッ 卜抗マウス EBI3（100 倍希釈、Abcam 社）お よび F4/80（500 倍希釈、Abcam 社）抗体・ ウサギ抗マウス p35（100 倍希釈、Epitomics 社) および CD163 (100 倍希釈、Santa Cruz 社) 抗体に室温で 2 時間反応させた。ヤギ抗ウサギ $\operatorname{IgG}$ (Alexa488) およびヤギ抗ラット IgG 抗 体 (Alexa546) に室温で 30 分間、DAPI に室 温で 15 分間反応後、コンフォーカル蛍光顕微 鏡（LSM510）で観察した。

\section{b ） CD4、CD8 および $\mathrm{B} 220$}

12 週齢 EBI3KO、p35KO およびWTマウス から摘出した精巣を OCT コンパウンドで包埋 後、迅速液体窒素で凍結、厚さ $5 \mu \mathrm{m}$ の切片 をクリオスタットにて作製した後、 $-20{ }^{\circ} \mathrm{Cの}$ アセトンで 2 分間固定し風乾した。組織切片 は、非特異的染色を阻止するため、ブロック エース（DS ファーマバイオメディカル社） 10 分、メタノールに $\mathrm{H}_{2} \mathrm{O}_{2}$ (final: $0.3 \%$ ) を加え た溶液に 30 分、VECTASTAIN ABC Elite kit (Vector 社) のブロッキング血清に 20 分間浸 漬した。次いで、PBSで希䣋した CD4（100
倍希釈、BD Biosciences 社)、CD8（50 倍希䣋、 BD Biosciences 社）およびB220（100 倍希 䣋、BD Biosciences 社) 抗体に室温で 2 時間 反応させた。ビオチン標識二次抗体（ウサギ 抗ラット IgG 抗体）に室温で 30 分間、ペルオ キシダーゼ標識アビジンに室温で 30 分間反応 後、 $0.02 \% \mathrm{H}_{2} \mathrm{O}_{2}$ 含有 $0.1 \%$ \%アミノベンチジ ン $50 \mathrm{mM}$ トリス緩衝液（pH7.6）で発色させ、 光学顕微鏡で観察し、陽性細胞数を単位面積あ たりで算出した。

\section{c ）自己抗体}

12 週齢 WT マウスからから摘出した精巣を OCT コンパウンドで包埋後、迅速液体窒素で 凍結、厚さ $5 \mu \mathrm{m}$ の切片をクリオスタットにて 作製した後、ー $20{ }^{\circ} \mathrm{C}$ の $95 \%$ エタノールで 10 分間固定し風乾した。組織切片は、非特異的染 色を阻止するため、ブロックエース 10 分、メ タノールに $\mathrm{H}_{2} \mathrm{O}_{2}$ (final: $0.3 \%$ ）を加えた溶液 に 30 分、VECTASTAIN ABC Elite kit のブロッ キング血清に 20 分間浸漬した。次いで、PBS で希釈した WT、EBI3KO および p35KO マウ ス血清（50 倍希釈）を室温で 2 時間反応させ た。Horseradish Peroxidase (HRP) 標識二 次抗体（抗マウス IgG 抗体）に室温で 30 分間 反応後、 $0.02 \% \mathrm{H}_{2} \mathrm{O}_{2}$ 含有 $0.1 \%$ ジアミノベン チジン $50 \mathrm{mM}$ トリス緩衝液（pH7.6）で発色 させ、光学顕微鏡で観察した。

\section{3. 分子生物学的観察}

2 週齢および 12 週齢 EBI3KO、p35KO および WT マウスの精巣、脾臓、肝臓、胸腺、顎下腺、 筋および脳から illustra RNAspin Mini RNA Isolation kit（GE Healthcare）を使用してプロト コルに従い totalRNA を抽出し、High-Capacity cDNA Archive Kit (Applied Biosystems) で逆転 写反応を行った。使用したプライマーDNA (Table.1) は EBI3、p35、IFN- $y 、$ IL-2、IL-4、 IL-6、IL-10 および TNF- $\alpha$ である。 Real-time PCR は SYBR Premix Ex Taq II（TaKaRa）および Thermal Cycler Dice Real-Time System TP 800（TaKaRa）を使用した。な打、各遺伝子 の発現量は、ハウスキーピング遺伝子である Glyceraldehyde 3-phosphate に対する相対発現 量とした。 
Table. 1 Primers used in this study. (文献35の改変)

\begin{tabular}{|c|c|c|c|}
\hline Name & $\begin{array}{l}\text { Accession } \\
\text { Number }\end{array}$ & Direction & Sequence $5^{\prime}$ to $3^{\prime}$ \\
\hline EBI3 & NM_015766.2 & $\begin{array}{l}\text { forward } \\
\text { reverse }\end{array}$ & $\begin{array}{l}\text { AGAGCCACAGAGCATGTCCAA } \\
\text { TGCACTCTGGGCTGGCTTAG }\end{array}$ \\
\hline p35 & NM_001159424.1 & $\begin{array}{l}\text { forward } \\
\text { reverse }\end{array}$ & $\begin{array}{l}\text { CCGGTCCAGCATGTGTCAA } \\
C A G G T T T C G G G A C T G G C T A A G A\end{array}$ \\
\hline IFN- $\gamma$ & NM_008337.3 & $\begin{array}{l}\text { forward } \\
\text { reverse }\end{array}$ & $\begin{array}{l}\text { ATCTGGAGGAACTGGCAAAA } \\
\text { TTCAAGACTTCAAAGAGTCTGAGGTA }\end{array}$ \\
\hline TNF-a & NM_013693.2 & $\begin{array}{l}\text { forward } \\
\text { reverse }\end{array}$ & $\begin{array}{l}\text { TCTTCTCATTCCTGCTTGTGG } \\
\text { TCTGGGCCATAGAACTGATGA }\end{array}$ \\
\hline IL-2 & NM_008366.3 & $\begin{array}{l}\text { forward } \\
\text { reverse }\end{array}$ & $\begin{array}{l}\text { TTGACGGACCCCAAAAGAT } \\
\text { GAAGCTGGATGCTCTCATCTG }\end{array}$ \\
\hline IL-4 & NR_027491.1 & $\begin{array}{l}\text { forward } \\
\text { reverse }\end{array}$ & $\begin{array}{l}\text { CATCGGCATTTTGAACGAG } \\
\text { CGAGCTCACTCTCTGTGGTG }\end{array}$ \\
\hline IL-6 & NM_031168.1 & $\begin{array}{l}\text { forward } \\
\text { reverse }\end{array}$ & $\begin{array}{l}\text { GCTACCAAACTGGATATAATCAGGA } \\
\text { CCAGGTAGCTATGGTACTCCAGAA }\end{array}$ \\
\hline IL-10 & NM_010548.2 & $\begin{array}{l}\text { forward } \\
\text { reverse }\end{array}$ & $\begin{array}{l}\text { GCCAGAGCCACATGCTCCTA } \\
\text { GATAAGGCTTGGCAACCCAAGTAA }\end{array}$ \\
\hline GAPDH & NM_008084.2 & $\begin{array}{l}\text { forward } \\
\text { reverse }\end{array}$ & $\begin{array}{l}\text { GCACCGTCAAGGCTGAGAAC } \\
\text { TGGTGAAGACGCCAGTGGA }\end{array}$ \\
\hline
\end{tabular}

\section{4. 統計}

統計解析は Microsoft Excel (Microsoft 社) を用いて行った。各種測定值は平均值士標準偏差 で表し、 $\mathrm{t}$ 検定にて統計学的に解析した。有意水 準は 0.05 以下とした。

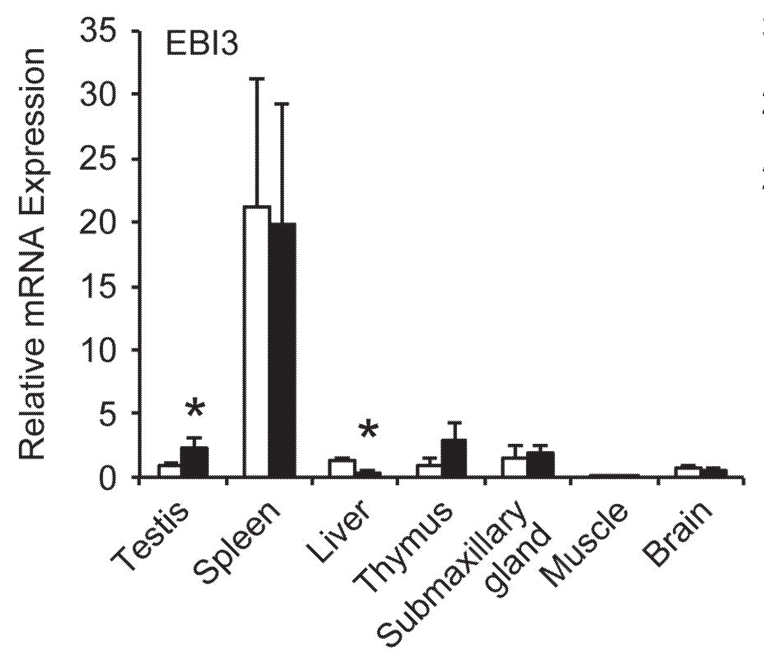

\section{結 果}

\section{1. 正常マウスの解析}

EBI3 およよび p35 は精巣、脾臓、肝臓、胸腺、 顎下腺、筋执よび脳に発現していた。さらに、精 巣内 EBI3 は2 週齢より 12 週齢マウスの方が多 く発現していた (Fig.1)。精巣内の蛍光染色の結

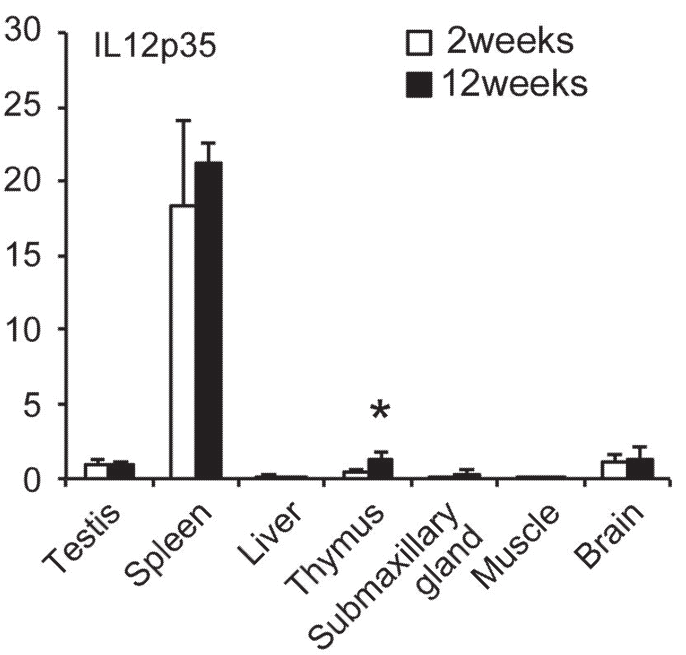

Fig. 1 Increased mRNA Expression of EBI3 in Testes of Adult WT Mice.（文献35の改変）

Total RNA was prepared from various tissues of 2-week-old and 10-week-old WT mice ( $\mathrm{n}=3$ /group) and subjected to real-time reverse-transcription polymerase chain reaction (RT-PCR) using various sets of primers. Ratio of relative mRNA expression to the mRNA expression level in testes of 2-week-old mice was calculated. Data are shown as means \pm standard deviation (SD). ${ }^{*} P<0.05$ compared with 2 -week-old mice. 
果から、EBI3 の発現は 2 週齢で検出されなかっ たが、12 週齢で精細管中の精子細胞・精子の頭 部と間質マクロファージ（CD163 陽性細胞）の 一部に検出された（Fig.2）。p35 の発現は 2 週 齢で血管内皮細胞や精細管の基底膜に検出され、 12 週齢で 2 週齢の発現に加え精細管中の精子細 胞・精子の頭部と間質マクロファージ（F4/80 陽性細胞）の一部に検出された（Fig.2）。12 週 齢の EBI3 陽性細胞の一部は p35 陽性だったこと から、IL-35 は精巣在住マクロファージの一部に 発現していることが示唆された (Fig.2)。

\section{2. $E B \mid 3 K O$ およびp35KO マウスの解析}

a ) 組織的解析

HE 染色切片の光学顕微鏡観察のレベルでは、 EBI3KO および p35KO マウスの間質中にリ ンパ球様細胞が精子形成障害を起こしている 精細管の近くに浸潤していることが観察され た（Fig.3A）。また、EBI3KO および p35KO マ ウスの組織化学染色の解析において、精子形 成障害像は WT マウスに比べ有意に高かった (Fig.3B)。

\section{b ) 病理学的解析}

CD4、CD8、B220 陽性細胞はWTマウスで 観察されなかったが (Fig.4A)、EBI3KO およ び p35KO マウスで陽性細胞浸潤像が観察さ れ (Fig. 4A)、陽性細胞数も有意に多かった

A

$$
\text { a: WT }
$$

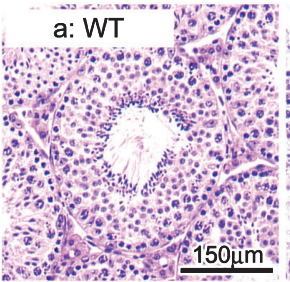

b: EBISKO

\section{b.: EBI}
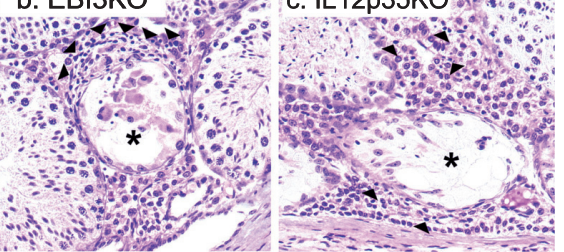

Fig. 3 Spermatogenic Disturbance in Mice Deficient in EBI3 and p35. (文献35の改変)

(A) Sections of testes of WT mice and mice deficient in EBI3 and p35 (12 weeks old; $n=10$ /group) were stained with hematoxylin and eosin. Infiltrating inflammatory cells $\left(^{*}\right)$ were observed in the interstitium around the seminiferous tubules, especially with exhibition of spermatogenic disturbance, in mice deficient in EBI3 and p35. (B) More than 100 round or oval seminiferous tubules were counted in each mouse, and the percentage of seminiferous tubules showing the disappearance of mature germ cells and desquamation of germinal epithelium was calculated. Data are shown as means \pm standard deviation (SD). ${ }^{*} \mathrm{P}<0.05$ and ${ }^{*} \mathrm{P}<0.001$ compared with WT mice, respectively. $\mathrm{KO}$, knockout.
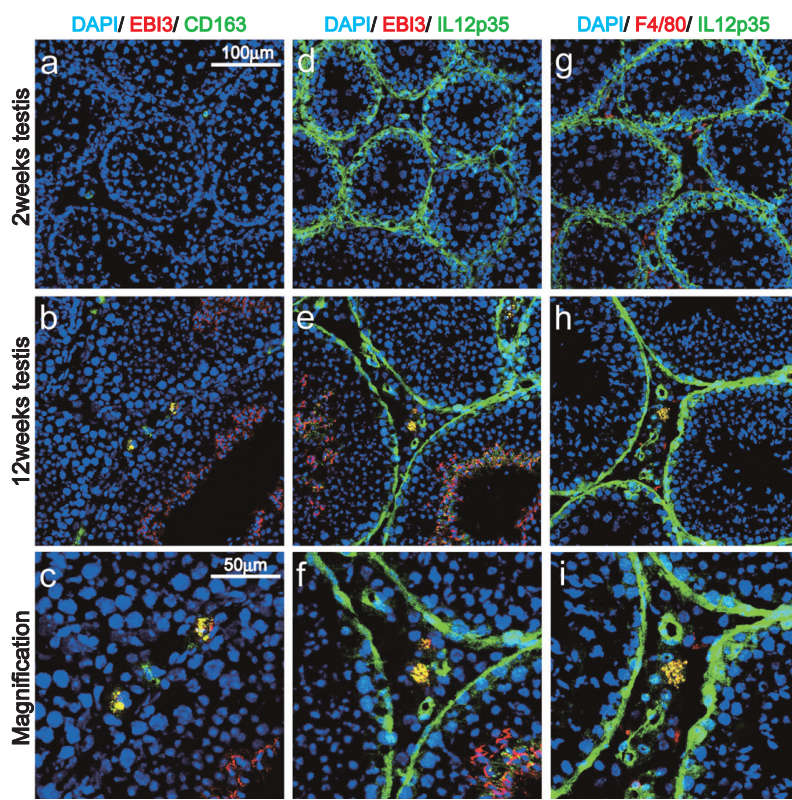

Fig. 2 EBI3 and p35 Double-Positive Resident Macrophages, Possibly Producing IL-35, in Interstitium. (文献35の改変)

Cryostat sections of testes of WT mice ( 2 and 12 weeks old; $n=5 /$ group) were immunohistochemically stained with anti-EBI3, anti-p35, anti-CD163, anti-F4/80, and DAPI. Confocal merged images are shown. F4/80 and CD163 are specific markers for whole macrophages and a subset of resident macrophages, respectively.

(Fig.4B)。EBI3KO および p35KO マウスの HE 染色で観察されたリンパ球様細胞は CD 4T、

B

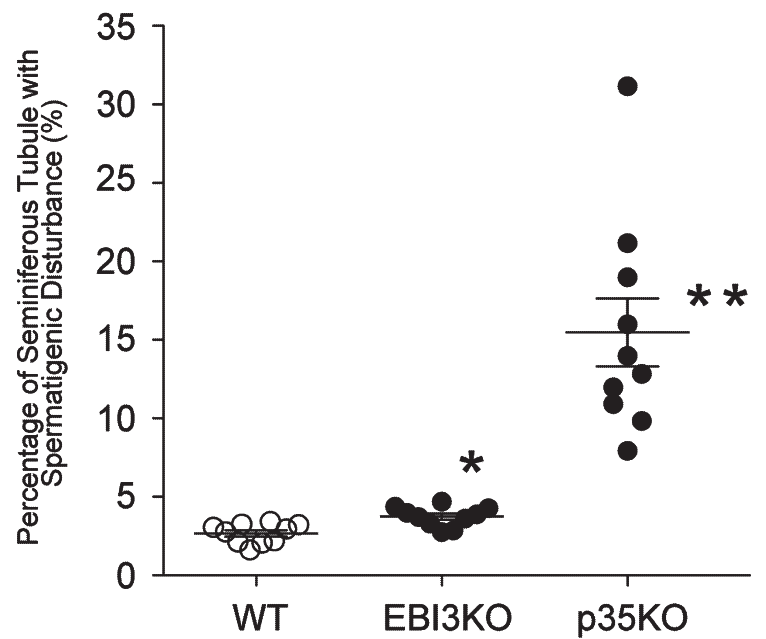


A

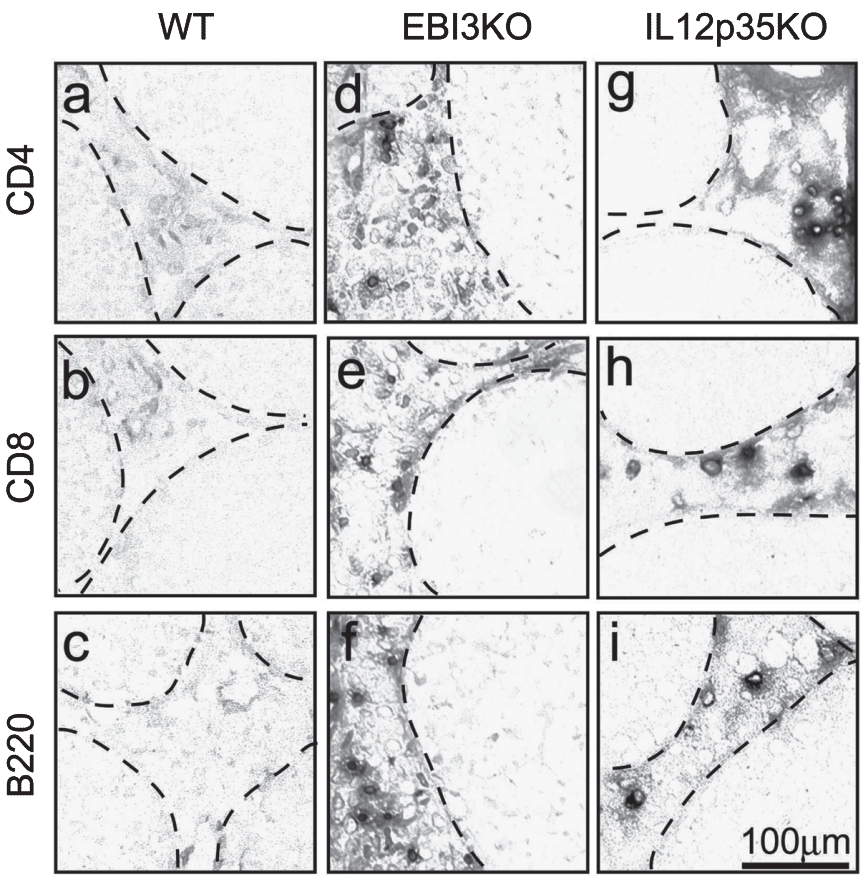

B

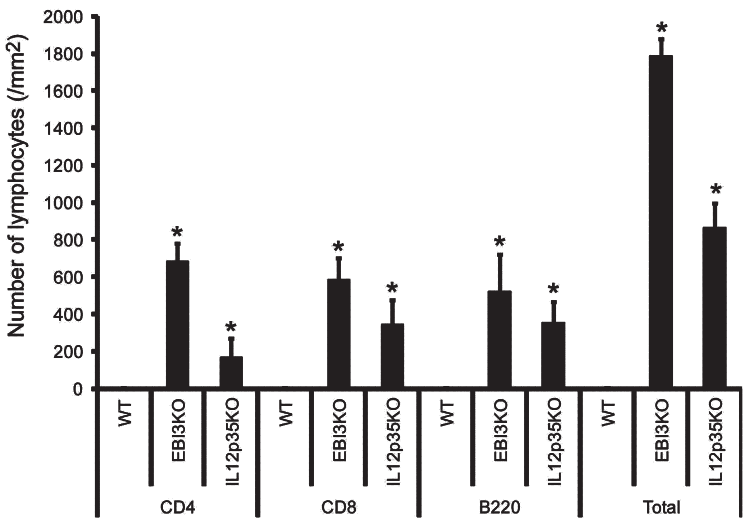

Fig. 4 Enhanced Infiltration of Lymphocytes in Testes of Mice Deficient in EBI3 and p35. (文献35の改変)

(A) Cryostat sections of testes of WT mice and mice deficient in EBI3 and p35 (12 weeks old; $n=5 /$ group) were immunohistochemically stained with anti-CD4, anti-CD8, or anti-B220. Positive cells are shown as grey spots. Dashed line indicates basal lamina of the seminiferous tubules. (B) The histopathological changes were evaluated by counting the number of infiltrating lymphocytes per $\mathrm{mm} 2$ of testicular interstitium. Data are shown as means \pm standard deviation (SD). ${ }^{*} \mathrm{P}<0.05$ compared with WT mice. KO, knockout.
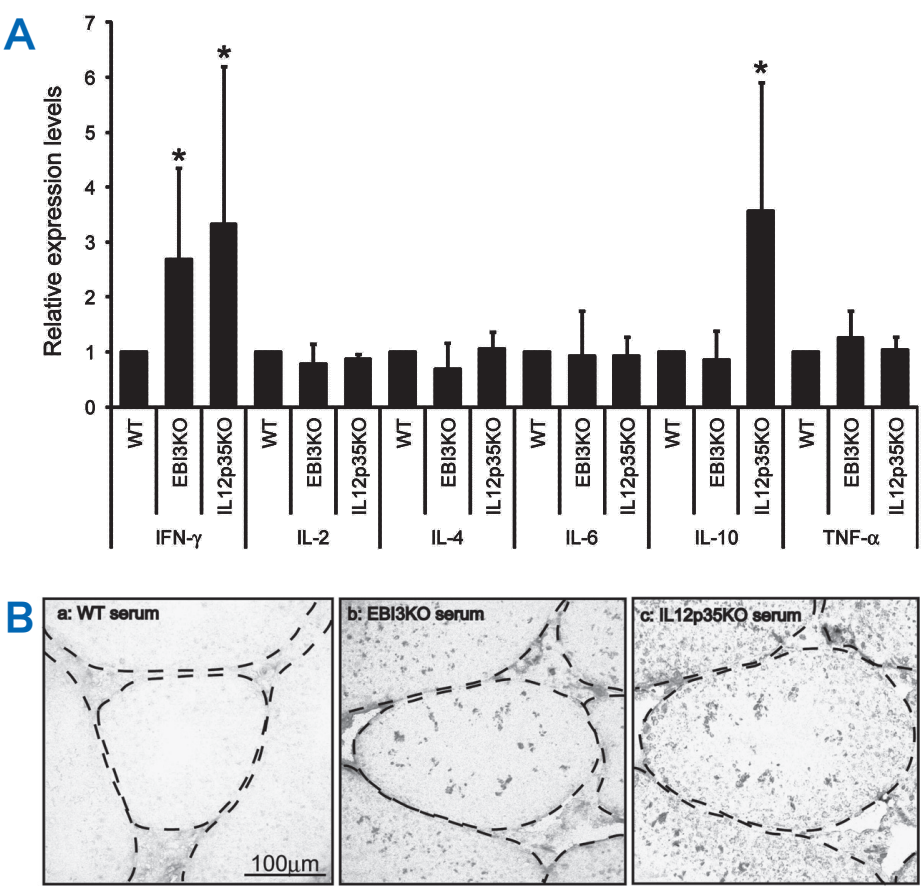

Fig. 5 Augmented mRNA Expression of IFN- $\gamma$ and Autoantibody Production in Mice Deficient in EBI3 and p35. (文献35の改変)

(A)Total RNA was prepared from testes of WT mice and mice deficient in EBI3 and p35 (12 weeks old; $\mathrm{n}=5$ /group) anc subjected to real-time reverse-transcription polymeras $\epsilon$ chain reaction (RT-PCR) using primers for various cytokines Ratio of relative expression level of each cytokine in deficient mice to that in WT mice was calculated. Data are shown as means \pm standard deviation (SD). ${ }^{* P}<0.05$ compared with WT mice. (B) For detection of serum autoantibodies, cryostat sections of testes of WT mice (12 weeks old) were immunohistochemically stained with diluted serum samples ( $n=5 /$ group) obtained from WT mice and mice deficient in EBI3 and p35 (12 weeks old). Positive cells are shown as grey spots. Dashed line indicates basal lamina of the seminiferous tubules. KO, knockout.
CD8T および B 細胞であることがわかった。ま た、サイトカインの発現から WT マウスに比べ、 EBI3KO で IFN- $\gamma$ が、p35KO マウスで IFN- $\gamma$
および IL-10 が有意に高かった (Fig.5A)。さら に、WT マウスの血清中に精巣細胞に対する自 己抗体の存在は確認出来なかったが、EBI3KO 
および p35KO マウスの血清中に精子細胞・精 子の頭部に対する自己抗体が存在する事がわ かった (Fig.4B)。

\section{考 察}

本研究は、正常マウスの解析により、IL-35 が 精巣内の CD 163 陽性マクロファージの一部に発 現することを明らかにした。また、EBI3KO およ び p35KO マウスにおいて、精子形成障害が認め られ、間質中には CD4、CD8、B220 陽性細胞が 浸潤することがわかった。さらに、EBI3KO およ び p35KO マウスの精巣中で IFN- $y$ の発現が増加 し、血清中に精子・精子細胞に対する自己抗体 が存在することがわかった。これらの結果より、 IL-35 は精巣微小環境において免疫学的抑制機構 に関わっている可能性が示唆された。

現在までに IL-35 を分泌する細胞は Treg 細胞 [15] 抢よび胎盤栄養膜細胞 ${ }^{[18]}$ と報告されてい る。Treg 細胞は IL-10、TGF- $\beta$ および IL-35 の ような免疫抑制性のサイトカインを分泌し、全身 免疫や局所免疫のホメオスタシスおよび免疫寛容 の調節に重要な役割を果たしている[19,20]。Treg 細胞の欠損は全身性の自己免疫疾患および炎症の 増悪を引き起こすが、EBI3KO および p35KO マ ウスに扔いて、精巣以外の臓器に炎症が誘導さ れているという報告はない[21,22]。本研究では、 IL-35 が精巣内の CD163 陽性細胞マクロファー ジの一部に発現し、EBI3KO および $\mathrm{p} 35 \mathrm{KO}$ マウ スにおいて、 $\mathrm{T}$ 細胞や $\mathrm{B}$ 細胞などの炎症細胞を伴 う有意な精子形成障害が誘導されることを明らか にした。

精巣は強い自己免疫源性を有する精子細胞・精 子をもつ一方、免疫学的に抑制された臓器であ り炎症が起こりにくい器官であると言われている [23]。精巣内はセルトリ細胞で構成される BTB で 免疫系の攻撃から護られているだけではなく、精 細管の外側にある間質細胞も免疫学的抑制環境の 形成や維持に関与している ${ }^{[5,23]}$ 。精巣間質には マクロファージ、Treg 細胞、ライディッヒ細胞 や内皮細胞が存在しており、それぞれの細胞から 様々なサイトカインが分泌され、精子形成、ホ ルモン産生、ホルモン分泌調節、細胞増殖、レ セプター発現調節、免疫抑制などに関係している [16]。精巣のマクロファージは間質に存在する細 胞の $20 \%$ ～ $25 \%$ を占め[24]、主に IL-10 が分泌
され免疫学的抑制環境の維持に関わっている[5]。 ラットの精巣マクロファージの実験において、精 巣間質マクロファージはスカベンジャー受容体で あるCD163の発現の有無から、newly arrived マクロファージと resident マクロファージに分 類される ${ }^{[25]}$ 。IL-1 $\beta$ 、TNF- $\alpha$ 、IL-6、activin A などの炎症性因子を発現することによって炎症 を促進する CD163 陰性マクロファージ (newly arrived）は精巣に炎症細胞浸潤を誘導させる。 一方、CD163 陽性マクロファージ（resident）は、 在住拄よび組織マクロファージなどと呼ばれ、精 巣間質マクロファージの 80 \%を占め、IL-10 を 産生し、精巣の免疫抑制環境に寄与している。 しかしながら、IL-10KO マウスの精巣おいて病 理組織学的な異常は報告されていない。本研究で は、IL-10 mRNA 発現の増加が p35KO マウスの 精巣で観察されたが、この現象は p35KO マウス のリンパ球浸潤や精子形成障害に対して代償的に 増加した可能性がある。精巣の免疫抑制環境を 維持する際、精巣 CD163 陽性マクロファージが IL-10 に加えて IL-35 を生産することにより、中 心的な役割を果たしていることが本研究で示唆さ れた。精巣 CD163 陽性マクロファージから精製 された IL-35 が生体外に対して生物活性を有し、 免疫抑制機能の行使に主な役割を果たすかどうか は今後の解明に期待される。また、精巣 CD 163 陽性マクロファージに加えて、EBI3 および p 35 は別々の精子細胞の先体に発現していた。生殖 細胞から分泌される TNF- $\alpha$ や TGF- $\beta$ などいくつ かのサイトカインは BTB や apical ectoplasmic specializationの再構築に関係しているが[26]、 精子細胞に発現している EBI3 および p35 の生理 学的な意義は不明なままである。

ヒト特発性男性不妊モデルである EAO はマウ スにTGCを 2 週おきに 2 回注射する事のみによっ て誘導でき、病理組織学的には $\mathrm{T}$ 細胞や $\mathrm{B}$ 細胞 の炎症細胞浸潤や精子形成障害が特徵である[2729]。リンパ球移入実験では、TGC を注射されたド ナーマウスの B 細胞や血清でなく CD $4+\mathrm{T}$ 細胞 がレシピエントマウスに EAO を引き起こすこと を認めたので、細胞性免疫（遅延型過敏症）主体 の疾患であることが考えられる[7]。さらに、IFN - $\gamma$ と TNF- $\alpha$ の mRNA 発現の増加や精子細胞に対 する自己抗体の出現が認められる[27-29]。これら EAO の病態は EBI3KO および p35KO マウスの病 態と非常によく似ている。以前、マウス精巣中へ IFN- $y$ を局所注射すると精子形成障害が誘導され 
ることが報告され、IFN- $\gamma$ の精巣毒性が証明され た[30]。さらに、IFN- $\gamma$ はセルトリ細胞の膜結合 型および可溶型の Fas の発現を増加させて、Fas リガンドによるセルトリ細胞への細胞毒性の影 響を受けやすくする事を報告した[31]。本研究で は EBI3KO およびp35KO マウスにおいて精巣中 でIFN- $y$ mRNA 発現は増加した。EBI3KO およ びp35KO マウスは精巣 CD 163 陽性マクロファー ジから免疫抑制性の IL-35 を産生することができ ないことから、IL-35 による免疫抑制がなくなり、 リンパ球が浸潤し、IFN- $\gamma$ mRNA 発現の増加した ことが考えられる。その後、おそらく精巣に産生 された IFN- $y$ は Fas-Fas リガンド相互作用によっ て、精細管を破損し、その結果、精子の漏出によ り、自己抗体の産生に至った可能性が考えられ る。しかし、本研究では EBI3KO および マウスが不妊になる事を確認出来なかった。この ことから、IL-35 だけでなく、他のサイトカイン やホルモンなどの様々な因子によって精巣の免 疫抑制環境が維持されている可能性が示唆される [32-34]。本研究では、免疫抑制因子である IL-35 がCD163 陽性マクロファージによって生産され、 精巣中の免疫抑制環境を維持することに寄与する ことを明らかにした。自己免疫性精巣炎が男性不 妊の重要な病因の一つであることから、精巣の免 疫抑制環境の詳細検討は男性不妊に関する重要な 情報を供給すると思われる。

\section{謝 辞}

稿を終えるにあたり、東海大学医学部基礎医学 系生体構造機能学領域の関口雅樹先生、田中理先 生、中野まゆみ技術職員、古谷祐生子秘書および 東京医科大学人体構造学講座の倉升三幸助手、小 川夕輝助手、阿保亜季子書記、平栁淑恵大学院生 のご協力・ご支援に深く謝意を表します。また、 本研究は科学研究費 - 基盤研究 C（26460809, 25340050）の助成を受けたものである。さらに、 今回発表した論文の内容抢よび図表は文献 35 を 一部改変したものである。

\section{引用文献}

1 ) Anton E. 1982. Preservation of the rat bloodtestis barrier after ligation of the ductuli efferentes, as demonstrated by intra-arterial perfusion with peroxidase. J Reprod Fertil. 66: 227-230.

2 ) Dym M, Fawcett DW. 1970. The bloodtestis barrier in the rat and the physiological compartmentation of the seminiferous epithelium. Biol Reprod. 3: 308-326.

3 ) Li N, Wang T, Han D. 2012 Structural, cellular and molecular aspects of immune privilege in the testis. Front Immunol 3: 152.

4 ) Itoh M, Terayama H, Naito M, Ogawa Y, Tainosho S. 2005 Tissue microcircumstances for leukocytic infiltration into the testis and epididymis in mice. J Reprod Immunol 67: 5767.

5 ) 伊藤正裕. 2001. 精巣機能とサイトカイン 一生殖とサイトカイン一。

6 ) Rodriguez MG, Rival C, Theas MS, Lustig L. 2006 Immunohistopathology of the contralateral testis of rats undergoing experimental torsion of the spermatic cord. Asian J Androl 8: 576-583.

7 ) Naito M, Terayama H, Hirai S, Qu N, Lustig L, , Itoh M, 2012 Experimental autoimmune orchitis as a model of immunological male infertility. Med Mol Morphol 45: 185-189.

8 ) Dokmeci E, Xu L, Robinson E, Golubets K, Bottomly K, Herrick CA. 2011. EBI3 deficiency leads to diminished $\mathrm{T}$ helper type 1 and increased $\mathrm{T}$ helper type 2 mediated airway inflammation. Immunology. 132:559-566.

9 ) Jacobo P, Perez CV, Theas MS, Guazzone VA, Lustig L. 2011 CD4+ and CD8+ T cells producing Th 1 and Th17 cytokines are involved in the pathogenesis of autoimmune orchitis. Reproduction 141:249-258.

10) Duan YG, Yu CF, Novak N, Bieber T, Zhu CH, Schuppe HC, Haidl G, Allam JP. 2011. Immunodeviation towards a Th17 immune response associated with testicular damage in azoospermic men. Int J Androl 34: e536-545.

11) Trinchieri G, Pflanz S, Kastelein RA. 2003 The IL-12 family of heterodimeric cytokines: new players in the regulation of $\mathrm{T}$ cell responses. Immunity 19: 641-644.

12) Kastelein RA, Hunter CA, Cua DJ. 2007 Discovery and biology of IL-23 and IL-27: 
related but functionally distinct regulators of inflammation. Annu Rev Immunol 25: 221 242.

13) Hall AO, Silver JS, Hunter CA. 2012 The Immunobiology of IL-27. Adv Immunol 115: 1-44.

14) Collison LW, Vignali DA. 2008 Interleukin- 35: odd one out or part of the family? Immunol Rev 226: 248-262.

15) Collison LW, Workman CJ, Kuo TT, Boyd K, Wang Y, Vignali KM, Cross R, Sehy D, Blumberg RS, Vignali DA. 2007. The inhibitory cytokine IL-35 contributes to regulatory T-cell function. Nature. 450: 566-569.

16) Niedbala W, Wei XQ, Cai B, Hueber AJ, Leung BP, McInnes IB, Liew FY. 2007. IL-35 is a novel cytokine with therapeutic effects against collagen-induced arthritis through the expansion of regulatory $\mathrm{T}$ cells and suppression of Th17 cells. Eur J Immunol. 37:3021-3029.

17) Banchereau J, Pascual V, O'Garra A. 2012. From IL-2 to IL-37: the expanding spectrum of antiinflammatory cytokines. Nat Immunol. 13: 925-931.

18) Mao H, Gao W, Ma C, Sun J, Liu J, Shao Q, Song B, Qu X. 2013. Human placental trophoblasts express the immunosuppressive cytokine IL35. Hum. Immunol. 74, 872-877.

19) Sakaguchi S. 2004. Naturally arising CD4+ regulatory $\mathrm{T}$ cells for immunologic selftolerance and negative control of immune responses. Annu. Rev. Immunol. 22, 531-562.

20) Sakaguchi S. 2011. Regulatory T cells: history and perspective. Methods Mol. Biol. 707, 3-17.

21) Mattner F, Magram J, Ferrante J, Launois P, Di Padova K, Behin R, Gately MK, Louis JA, Alber G. 1996. Genetically resistant mice lacking interleukin-12 are susceptible to infection with Leishmania major and mount a polarized Th2 cell response. Eur. J. Immunol. 26, 15531559.

22) Nieuwenhuis EE, Neurath MF, Corazza N, Iijima H, Trgovcich J, Wirtz S, Glickman J, Bailey D, Yoshida M, Galle PR, Kronenberg M, Birkenbach M, Blumberg RS. 2002. Disruption of $\mathrm{T}$ helper 2-immune responses in EpsteinBarr virus-induced gene 3-deficient mice. Proc. Natl. Acad. Sci. U S A. 99, 16951-16956.

23) Maddocks S, Setchell BP. 1990. Recent evidence for immune privilege in the testis. J Reprod Immunol. 18:9-18.

24) Hedger MP. 2002. Macrophages and the immune responsiveness of the testis. J. Reprod. Immunol. 57, 19-34.

25) Winnall WR, Hedger MP. 2013. Phenotypic and functional heterogeneity of the testicular macrophage population: a new regulatory model. J. Reprod. Immunol. 97, 147-158.

26) Li MW, Mruk DD, Lee WM, Cheng CY. 2009. Cytokines and junction restructuring events during spermatogenesis in the testis: an emerging concept of regulation. Cytokine Growth Factor Rev. 20, 329-338.

27) Naito M, Itoh M. 2008 Patterns of infiltration of lymphocytes into the testis under normal and pathological conditions in mice. Am. J. Reprod. Immunol. 59, 55-61.

28) Naito M, Terayama H, Hirai S, Qu N, Kawata S, Itoh M. 2009. Histopathology of the tubuli recti at the start of experimental autoimmune orchitis in mice. Med. Mol. Morphol. 42, 230235.

29) Terayama H, Naito M, Qu N, Hirai S, Kitaoka M, Ogawa Y, Itoh M. 2011. Intratesticular expression of mRNAs of both interferon gamma and tumor necrosis factor alpha is significantly increased in experimental autoimmune orchitis in mice. J. Reprod. Devel. 57, 296-302.

30) Natwar RK, Mann A, Sharma RK, Aulitzky W, Frick J. 1995. Effect on human gamma interferon on mice testis: a quantitative analysis of the spermatogenic cells. Acta. Eur. Fertil. 26, 45-49.

31) Riccioli A, Starace D, D'Alessio A, Starace G, Padula F, De Cesaris P, Filippini A, Ziparo E. 2000. TNF-alpha and IFN-gamma regulate expression and function of the Fas system in the seminiferous epithelium. J. Immunol. 165, 743-749.

32) Fijak M, Meinhardt A. 2006. The testis in immune privilege. Immunol. Rev. 213, 66-81. 
33) Li N, Wang T, Han D. 2012. Structural, cellular and molecular aspects of immune privilege in the testis. Front. Immunol. 3, 152.

34) Meinhardt A, Hedger MP. 2012. Immunological, paracrine and endocrine aspects of testicular immune privilege. Mol. Cell. Endocrinol. 335, 6068.
35) Terayama H, Yoshimoto T, Hirai S, Naito M, Qu N, Hatayama N, Hayashi S, Mitobe K, Furusawa J, Mizoguchi I, Kezuka T, Goto H, Suyama K, Moriyama H, Sakabe K, Itoh M. 2014. Contribution of IL-12/IL-35 Common Subunit p35 to Maintaining the Testicular Immune Privilege. PLoS One. 23, e96120.

\title{
Interleukin-35 plays a pivotal role in maintaining the testicular immune privilege
}

\author{
Hayato Terayama a)*, Takayuki Yoshimoto b), Munekazu Naito c), Shuichi Hirai d), \\ Ning Qu d), Naoyuki Hatayama d), Shogo Hayashi d), Teruhisa Kanazawa a), \\ Kaori Suyama a), Kou Sakabe a) and Masahiro Itoh d) \\ a) Department of Anatomy, Basic Medical Science, \\ Tokai University School of Medicine \\ (143 Shimokasuya, Isehara-si, Kanagawa, 259-1193, Japan) \\ b) Department of Immunoregulation, Institute of Medical Science, \\ Tokyo Medical University \\ (6-1-1 Shinjuku, Shinjuku-ku, Tokyo, 160-8402, Japan) \\ c) Department of Anatomy, Aichi Medical University \\ (1-1 Yazakokarimata, Nagakute-si, Aichi, 480-1195, Japan) \\ d) Department of Anatomy, Tokyo Medical University \\ (6-1-1 Shinjuku, Shinjuku-ku, Tokyo, 160-8402, Japan) \\ *Corresponding author: Hayato Terayama \\ Tel: +81-463-931121 (ext.2513) \\ E-mail:terahaya@tokai-u.jp
}

Key words:

testis, Interleukin-35 (IL-35)

\begin{abstract}
:
Background: Testis is known as one of the immunologically privileged organs. In particular, bloodtestis barrier formed by Sertoli cells protects autoimmunogeneic spermatozoa and spermatid from attack by the self-immune system. Moreover, it was demonstrated that Sertoli cells, Leydig cells and a few population of testicular macrophages exhibit immunosuppressive activity. Recent studies also


suggest a possibility that some cytokines in the testis contribute to maintaining the immune privilege. Interleukin (IL)-35 is a heterodimeric cytokine composed of Epstein-Barr virus-induced gene 3 (EBI3) and the p35 subunit of IL-12. Although it is IL-35 has an important role in immunosuppression, its role in the testis remains unknown. Methods and Findings: In the present study, we investigated the role of intra-testicular IL-35 by histochemistry, immunohistochemistry and real-time RT-PCR using wildtype C57BL/6 mice and EBI3- and p35-deficient mice. EBI3 expression was detected in a part of CD163positive macrophages and acrosomal regions of spermatids in testis of wild-type mice. Intriguingly, p35 expression was coincidently detected in a part of EBI3- and F4/80-positive macrophages, and also in basal lamina of seminiferous tubules, endothelial cells and acrosomal region of spermatids. A significant increase in the number of seminiferous tubules with spermatogenic disturbance was observed in both EBI3- and p35-deficient mice, compared with that in wild-type mice. Especially, p35-deficient mice showed severe spermatogenic disturbance. Moreover, CD4-, CD8- and B220-positive infiltrating cells were detected in the testicular interstitium of EBI3- and p35-deficient mice, but not of wild-type mice. Intra-testicular mRNA expression of interferon-gamma was significantly increased in EBI3- and p35deficient mice. A similar increase in the expression of IL-10 was observed only in p35-deficient mice. Finally, autoantibodies to spermatids were detected in sera obtained from EBI3- and p35-deficient mice, but not from wild-type mice. Conclusions: In testis, there are EBI3- and p35-double positive macrophages, possibly producing immunosuppressive IL-35. And, lack of either EBI3 or p35 causes infiltration of lymphocytes into testis and spermtatogenic disturbance. These results indicate that IL-35 plays an important role in maintaining the testicular immune privilege. 